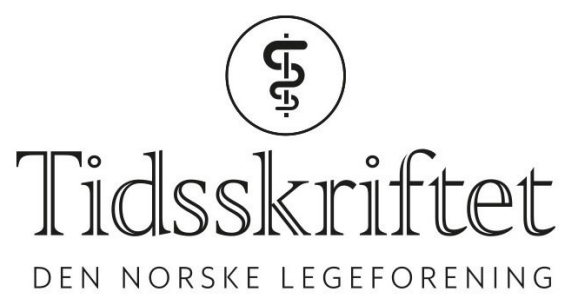

\title{
Hva gjør Legeforeningen for å avskaffe foretaksmodellen?
}

DEBATT

\author{
PER VAGLUM \\ E-post:p.j.w.vaglum@medisin.uio.no \\ Per Vaglum er dr.med., spesialist i psykiatri og professor emeritus ved Avdeling for medisinsk \\ atferdsvitenskap, Universitetet i Oslo. \\ Forfatteren har fylt ut ICMJE-skjemaet og oppgir ingen interessekonflikter.
}

Helseforetaksmodellen er nå 18 år, men skaper fortsatt store problemer for god klinisk praksis. Den må avskaffes - og Legeforeningen må bidra til det.

Helseforetaksmodellen ble innført i 2001. Den representerte et klart brudd med en tillitsbasert organisasjonsmodell og vi fikk en kontroll- og effektivitetsmodell isteden (1). Det skjedde uten de vanlige utredninger, høringer og forankring hos helsepersonellet. Fokus ble flyttet fra omsorg, kvalitet, behandlerautonomi og lege-pasient-relasjoner over til produksjon, kontroll, kvantitet, dokumentasjon, redusert behandlerautonomi og nedvurdering av lege-pasient-forholdet. Et nytt og omfattende byråkrati ble etablert. Hvordan behandlerne skulle løse de nye oppgavene og samtidig ivareta faglige og etiske retningslinjer for menneskebehandlende profesjoner, var lite gjennomtenkt.

I Tidsskriftet nr. 10/2019 er det en rekke opplysende referater fra landsstyremøtet 2019, og mange viktige spørsmål ble diskutert. Krisen i fastlegeordningen fikk som ventet stor oppmerksomhet (2). Det ble understreket at "pasientnær ledelse er viktig», at "pasienten må stå i sentrum», og at «fragmenterte tjenester gjør dette vanskelig» (3). Et prinsipprogram ble vedtatt uten diskusjon, antagelig fordi formuleringene der er så generelle at alle leger er enige i dem. Det interessante spørsmålet (elefanten i rommet?) er, og det blir ikke nevnt i referatene, hva Legeforeningen vil gjøre for å oppnå de forbedringer og mål som prinsipprogrammet lister opp. For å oppnå disse målene kommer man ikke utenom at foretaksmodellen må skrotes.

Nå må det skje. Nok er nok

Dyktige kolleger på ulike ledernivåer har hittil tappert og lojalt forsøkt å praktisere foretaksmodellen slik den er tenkt. Det gikk ikke uten protester i starten, og det går fortsatt ikke. Mistilliten til modellen, og etter hvert til dem som har styrt etter denne, har vedvart og vokst. Mistilliten har spredd seg til ledelsen på alle nivåer. Ifølge vanlig ledelsesteori vil alle forandringer møte motstand i organisasjonen. Politikerne og departementet oppfatter gjerne slik motstand som «støy». Ledelsesteori tilsier at slik støy raskt stilner. Men etter 18 år har støyen rundt foretaksmodellen fortsatt ikke stilnet, den har heller økt. Modellen er åpenbart et enormt feilslag. Den politiske og departementale ledelsen har dessverre ikke fra 
starten av hatt en utprøvende og kritisk holdning til hvordan modellen har fungert i praksis. De har heller ikke vært villig til å skrote det hele når det oppsto alvorlige, negative erfaringer. Nå må det skje. Nok er nok.

Foretaksmodellen ble innført på samme måte som kristendommen i Norge: ved sverdet. Motforestillinger ble møtt med uttalelser som at effektivitet var det samme som kvalitet (1). Det er pinlig at det for tiden er psykologer og Psykologforeningen - og ikke Legeforeningen - som i størst grad fronter opposisjon mot foretaksmodellen i mediene. Tidsskriftets redaktør påpeker helt korrekt at vi i den kommende nasjonale helseplanen nå risikerer å få den samme meningsløse organiseringen, byråkratiseringen og prioriteringen bort fra den kliniske virkeligheten (4). Har myndighetene ikke lært noe av den mislykkete foretaksmodellen? Legeforeningen har forhåpentligvis lært mye.

Når det er en kognitiv dissonans mellom hva behandleren (og profesjonen) mener er faglig og etisk korrekt praksis, og en uforsvarlig praksis som blir pålagt ovenfra, er det tre muligheter. Man kan slutte i jobben. Man kan passivt underkaste seg det nye regimet, noe som fort kan lede til ansvarsfraskrivelse, kynisme, faglig utarming og utbrenthet. «Jeg må først sørge for at jeg har ryggen fri, deretter sikre frie luftveier», som en kollega sa. Den tredje muligheten er å protestere, mange sammen, og om nødvendig streike.

Det er pinlig at det for tiden er psykologer og Psykologforeningen - og ikke Legeforeningen - som i størst grad fronter opposisjon mot foretaksmodellen i mediene

Heldigvis velger de fleste kolleger det tredje alternativet, selv om det koster. Det kommer stadig varsler i mediene om uønskete konsekvenser, også av velmente, men mislykkete tiltak, sist "pakkeforløp» i psykiatri og rusfeltet. Slike varsler møtes fortsatt ofte med taushet og formalistisk repetering av instrukser. Selvsagt skaper slik «døvhørt» ledelse fra toppen og nedover mistillit til alt den gjør. Også til planer om nybygging. I sitt foredrag ved Psykiatriveka 2017 «Staten og psykiateren» ga direktøren ved Helsetilsynet følgende råd: Faglige erfaringer og råd fører ikke til forandring. Bygg opp nettverk til sentrale myndigheter og politikere. Allier dere med pasientorganisasjoner.

Hvis Legeforeningen har bygget nettverk mot sentrale personer, har det hittil ikke resultert i noen radikal forandring. Foretaksmodellen er utgått på dato. Den nye organisasjonsmodellen må bygges nedenfra. Forandringene må være så radikale at hver eneste pasient og behandler merker dem. De må fjerne nåværende, og meget tydelige hindringer for forsvarlig, ansvarsfull og kvalitativ god klinisk praksis og vende tilbake til menneskebehandlende profesjoners velkjente verdier og faglighet. Innsatsstyrt finansiering må snarest opphøre. Den fører til at man dropper eller nedprioriterer behandlingsaktiviteter, som terapeutiske samtaler med pasient og familie. Den gjør at det lønner seg å utrede mange pasienter, men ikke gi dem nevneverdig behandling - og å skrive ut og reinnlegge mange.

Omleggingen til en faglig og etisk forsvarlig organisasjonsmodell blir det (nye?) direktører, fagsjefer, styrer og politisk ledelse som må iverksette. De som har kontakt med den kliniske virkeligheten, vil neppe ha problemer med dette når klarsignalet kommer ovenfra. Legeforeningen må ikke lenger være en tilsynelatende lojal garantist for foretaksmodellen, men tvert imot fronte kravet om en radikal endring. Hva er Legeforeningens handlingsplan for dette?

\section{LITTERATUR:}

1. Slagstad R. Helsefeltets strateger. Tidsskr Nor Legeforen 2012; 132: 1479-85. [PubMed][CrossRef]

2. Wærnes D. Regjeringen gjør ikke nok for å løse fastlegekrisen Tidsskr Nor Legeforen 2019; 139: 990.

3. Sandli MH, Lerum SV. Bedre helsetjeneste til dem som trenger det mest. Tidsskr Nor Legeforen 2019; 139: 992. 
4. Brean A. Ny tids tale. Tidsskr Nor Legeforen 2019; 139. doi: 10.4045/tidsskr.19.16.01.

[PubMed][CrossRef]

Publisert: 13. januar 2020. Tidsskr Nor Legeforen. DOI: 10.4045/tidsskr.19.0723

Mottatt 9.11.2019, første revisjon innsendt 26.11.2019, godkjent 27.11.2019.

(C) Tidsskrift for Den norske legeforening 2020. Lastet ned fra tidsskriftet.no 